\title{
Environmental Management System ISO 14001 and National Economies in EU Member States
}

\author{
Stojan $\check{C ̆ r v}^{*}$ \\ ITW Appliance Components d.o.o., Poljubinj 89E, 5220 Tolmin, Slovenija \\ stojan.crv@gmail.com
}

\begin{abstract}
:
Research Question (RQ): In terms of the rising environmental awareness importance our main research question was if national economies in EU member states have any effect on the number of ISO 14001-certified organizations.

Purpose: The primary purpose of the research was to obtain the answer to our research problem of whether national economies in EU member states affect the number of organizations that have the certified ISO 14001 environmental management system in place and to explore the trend of the number of certificates in the European Union.

Method: An empirical analysis was conducted using the data of ISO, the International Organization for Standardization, on the number of ISO 14001 certificates in 2019, and the data of Eurostat for selected national macroeconomic indicators. Our research included a survey of $28 \mathrm{EU}$ member states in 2019. The distribution of data is shown by bar charts. Statistical processing of numerical data used in the analysis was done by means of the Minitab software. Prior to statistical processing, nonnormally distributed data was transformed with the Johnson transformation method. The hypotheses were verified on the basis of the calculated Pearson correlation coefficients "r « between the examined factors.
\end{abstract}

Results: In 2019, there were 92,290 organizations in EU member states that held the ISO 14001 certificate. In absolute numbers of certificates, the top five countries are the so-called »older EU member states«, namely Italy, Spain, the United Kingdom, Germany and France. The highest number of certificates per one billion EUR of GDP was identified in the so-called »new member states «, namely Bulgaria, Croatia, Romania, the Czech Republic and Estonia. The main finding of our research is that the level of GDP affects the number of ISO 14001 certificates in EU member states since, according to the calculated Pearson correlation coefficient, there is a strong correlation between the two studied factors. Other examined national macroeconomic factors, such as general government expenditure for environmental protection, environmental tax revenues and global competitiveness index rating, have no effect on the number of ISO 14001 certificates.

Organization: The research provides organizations with an overview of the current situation regarding the number of ISO 14001 certificates in EU member states. The shown positive trend in the growth of the number of certificates can be an additional motivation factor for those organizations that have yet to decide on certification.

Society: The finding that the certified ISO 14001 environmental management system is a useful and effective management tool is important both for organizations as well as wider society because it brings enhanced environmental performance and sustainability, competitive advantage as well as financial and organizational performance.

Originality: Considering that our research included all $28 \mathrm{EU}$ member states in 2019 and the fact that the latest publicly available data on the number of ISO 14001 certificates in 2019 was used, it is our belief that our research is unique from this point of view.

Limitations / further research: The research was narrowed down to $28 \mathrm{EU}$ member states. The hypotheses were verified on the basis of the latest publicly available data for year 2019 published by ISO. It would make sense to continue our research and, in addition to our four discussed factors, to examine other national macroeconomic indicators. Thus, it would be possible to establish whether there are other factors, in addition to GDP, that have a positive impact on the growth of the number 
of ISO 14001 certificates. Moreover, the research could also include other countries on the European continent that are not necessarily EU member states.

Keywords: environmental management system, ISO 14001, certification, environmental protection, national economic indicators, European Union.

\section{Introduction}

In today's business environment, organizations are faced with increasing market and institutional pressures to act in a socially responsible and environmentally friendly manner (Treacy, Humphreys, McIvor, \& Lo, 2019, p. 319). Therefore, today's organizations that wish to be competitive in the global market need to meet the demands of an ever-greater number of stakeholders, both internal and external. Environmental sustainability is becoming a determining factor enabling organizations to succeed (Preziosi, Merli, \& D’Amico, 2016, p. 1). The challenge of achieving sustainable development is large and pressing for organizations (Polasky et al., 2019, p. 5237).

Due to global environmental degradation over the past few decades, environmental management has become a top priority at a national and international level to achieve sustainable development and operations (Liu, Yuan, Hafeez, \& Li, 2019, p. 1241). In this same period, the ISO 14001 environmental management system certification, integrating corporate environmental protection policies and programs, has become a growing practice among companies all over the world (Murmura, Liberatore, Bravi, \& Casolani, 2018, p. 691). Therefore, voluntary environmental certification, such as ISO 14001, has gained momentum, since it was shown to have a positive impact on corporate environmental performance (Erauskin-Tolosa, Zubeltzu-Jaka, Heras-Saizarbitoria, \& Boiral, 2020, p. 1145).

The growing concern about the impact of human activities on the environment has also drawn the attention of governments. It has become a priority of organizations to demonstrate their adequate environmental performance, and they can do so by means of the international environmental management system standard ISO 14001 (Hikichi, Salgado, \& Beijo, 2017, p. 242). ISO 14001 has become one of the main tools of organizations when it comes to their handling of environmental aspects and reducing impact on the environment (Campos, de Melo Heizen, Verdinelli, \& Cauchick, 2015, p. 286). It namely stands out as one of the most widely used systems for proactively managing corporate environmental aspects and processes in organizations (Oliveira, Oliveira, Ometto, Ferraudo, \& Salgado, 2016, pp. 1384-1392).

The ISO 14001 environmental management system is an excellent strategy for increasing the satisfaction of community in which an organization operates, the awareness of employees who help shape the community through their work, and for enhancing sustainable development. Moreover, knowledge in environmental protection obtained by organizations can be used by them as strategic competitive advantage. (Chiarini, 2017, p. 852) 


\section{Theoretical framework}

ISO 14001 is a leading international standard for managing interaction between companies' operating procedures and their natural environment. The trend of globalization and pressures from different stakeholders, including customers, governments and communities, has forced organizations to become environmentally friendly (Sorooshian, Qi, \& Li Fei, 2018, pp. 103104). The ISO 14001 standard thus arose out of the need for a wider use of a uniform environmental management system (Sousa Lira, Gomes Salgado, \& Alberto Beijo, 2019, p. 276). Standardization of management practices involves harmonization of procedures among organizations from different countries. The benefits of standardization in the global economy have turned the adoption of certified management standards by means of which organizations reduce their impact on the environment into a global phenomenon (Orcos, Pérez-Aradros, \& Blind, 2018, pp. 850-859).

The ISO 14001 environmental management system has become a key success factor of competitiveness in the market. Since its first issue in 1996, the ISO 14001 standard has been revised twice. The first revision in 2004 only introduced minor, non-substantial changes. In 2015 , however, the standard underwent substantial content revision. The revision was prompted by changes in the environmental context in which organizations operate, taking into consideration environmental issues (e.g. climate change, biodiversity loss, degradation of ecosystems, etc.) and experience obtained through the environmental management process. (Bravi, Santos, Pagano, and Murmura, 2020, pp. 2599-2600)

The ISO 14001 environmental management system is a voluntary tool by means of which organizations manage the environmental aspects of their operations (Merli \& Preziosi, 2018, p. 4532), while its adaptability makes it one of the most useful tools of environmental sustainability and worldwide competitive advantage. The ISO 14001-certified organizations have continuously demonstrated greater environmental performance, while the popularity of the certificate is increasing due to the growing concerns about climate change (Ikram, Mahmoudi, Syed Zulfiqar, \& Mohsin, 2019, p. 1). This is also confirmed by the results of the survey conducted by Arimura, Darnall, Ganguli, and Katayama (2016, pp. 565-566) who note that the certified ISO 14001 environmental management system used as a voluntary tool by organizations to reduce their environmental impact is useful and effective.

The environmental management standard is an important voluntary management tool that aims at reducing the environmental impact of firms' activities (Ozusaglam, Robin, \& Wong, 2017, p. 1318) and provides a systematic framework enabling companies to control their impact in the long run (Arocena, Orcos, \& Zouaghi, 2020, p. 956). The ISO 14001 environmental management standard provides a guideline for organizations to continuously improve their environmental performance, while the certificate serves to demonstrate organizational commitment to sustainable production processes (Salim et al., 2018, p. 1). Despite the fact that ISO 14001 does not set requirements regarding the achieved performance but merely sets up a framework for an organization to reduce its environmental impacts, the findings of the study 
conducted by Maletič, Podpečan, and Maletič (2015, pp. 884-885) show that it can support actions required to improve corporate sustainability performance. But in order to use ISO 14001 as an effective tool for fostering the change towards sustainable development, organizations need to make a step beyond ISO 14001's environmental focus and address the social aspect as well. The ISO 14001 certificate guarantees that an organization has a structured environmental management system in place. Thus, an organization can consistently control its significant impacts on the environment and continually improve operations and business (Reis, Neves, Hikichi, Salgado, \& Beijo, 2018, p. 12).

ISO 14001 is a standard based on the concept that better environmental performance can be achieved when environmental aspects are systematically identified and managed, contributing greatly to sustainability, pollution prevention, improved environmental performance and compliance with applicable laws (Ciravegna Martins da Fonseca, 2015, p. 37). It is also an effective management tool. The adoption of ISO 14001 in an organization's operations is a positive strategic decision for its management because it does not only help them reduce their environmental impact, but also increases financial profitability (Arocena, Orcos, \& Zouaghi, 2020, p. 964). The ISO 14001 standard is also a tool that improves process efficiency, reduces costs, improves corporate image and ultimately contributes to a positive economic bottom line (Maletič, Podpečan, \& Maletič, 2015, pp. 884-885), as it is not focused on what is produced but on how this is done, also taking into consideration compliance with legislation. From the methodological point of view, the basic principle of ISO 14001 is continuous improvement, including the measurement and record of environmental performance (Di Noia \& Nicoletti, 2016, p. 96).

According to Reis, Neves, Hikichi, Salgado, and Beijo (2018, p. 12), the benefits found by certified companies can be classified into three categories:

- internal benefits, such as organizational improvement, environmental performance and reduced costs of raw materials,

- external benefits, such as improved image, expansion of customer base and investor market, and

- relations benefits which include environmental awareness and competitiveness.

Environmental management is a business practice that may bring various benefits to companies, such as improved efficiency, increased revenues, greater customer satisfaction and improved image (Tarí, Molina-Azorín, \& Heras, 2012, p. 298). ISO 14001 certification is widely considered as the tool of choice for driving waste minimization efforts (Singh, Brueckner, \& Padhy, 2015, p. 287) and eco-innovation which has become an important instrument to help companies reduce their environmental impact and gain a competitive advantage in increasingly competitive environments (Hojnik \& Ruzzier, 2017, p. 581). The requirements of ISO 14001, such as environmental training, pollution prevention and waste reduction, have a positive impact on organizations' performance (Treacy, Humphreys, McIvor, \& Lo, 2019, p. 326). The findings of research conducted by Ikram, Zhang, Sroufe, and Shah (2020, pp. 218-229) show 
that through renewable energy consumption and the adoption of ISO 14001 certification, companies significantly reduce $\mathrm{CO}_{2}$ emissions.

Certification of the environmental management system in compliance with ISO 14001 is becoming increasingly strategic in the global market. However, many organizations still tend to use the tool just because they are interested in grasping some short-term opportunities, such as simplifications in obtaining environmental permits and financial incentives offered by various governments. Moreover, in times of economic and financial crises, it seems that the business community is even less interested in organizations that give priority to economic, social and environmental sustainability (Di Noia \& Nicoletti, 2016, p. 94). A study performed by Ejdys, Matuszak-Flejszman, Szymanski, Ustinovichius, Shevchenko, and Lulewicz-Sas (2016, p. 67) has demonstrated that the leading role and the involvement of the top management play an important role in the process of continuous improvement of the environmental management system. The stop down « approach constitutes a crucial element in improving management systems as the involvement of the top level management ensures the involvement of other staff members and motivates them for continuous improvement.

ISO 14001 certification can also be viewed as an organizational response to institutional pressure to act proactively towards the environment (Riaz, Saeed, Baloch, Nasrullah, \& Khan, 2019 , p. 1). Environmental awareness is an important motive for certification, while environmental protection and improved image and reputation are considered by ISO14001certified companies as major benefits (Murmura, Liberatore, Bravi, \& Casolani, 2018, p. 694). A study conducted by Reis, Neves, Hikichi, Salgado, and Beijo (2018, p. 12) has shown that companies seeking ISO 14001 certification are usually companies already established in the market and having economic power, because they want to attract new customers, new investors and improve the company's image.

Bravi, Santos, Pagano, and Murmura (2020, pp. 2599-2600) have found through their research that companies of different sizes are driven by the same motives to obtain ISO 14001 certification; however, the size of an organization does affect the level of motivation for certification. Thus, it is the largest organizations that are most interested in the adoption of the ISO 14001 environmental management system, since this improves their public image and satisfies their need for continuous improvement of their environmental performance. Smaller organizations, on the other hand, primarily see the certified ISO 14001 system as an important element of their competitiveness. However, organizations, small ones in particular, see the adoption and certification of the environmental management system as a bureaucratic burden and something that increases their costs. They do not recognize it as a strategic business tool and do not acknowledge its positive environmental impact in the long run. Preziosi, Merli, and D'Amico (2016, p. 1) note that small companies are often faced with major challenges when implementing ISO 14001, which is due to the lack of human and financial resources. Additionally, they are driven by a short-term orientation that does not allow the exploitation of the advantages of sustainability investments, which generally have a long-term payoff. 
The most relevant factor for successful implementation of the environmental management system is involvement of employees, followed by top management commitment and development of environmental technical skills. Top management should not only be focused on defining an organization's strategies, but should manage the process of raising awareness and informing employees of the proper attitude towards environmental issues (Chiarini, 2019, p. 801). When an organization prepares for ISO 14001 certification, this sends a positive signal to the market which usually responds favorably thereto (Lee, Noh, Choi, \& Rha, 2017, p. 117). Some firms declare their environmental commitment through symbolic adoption of ISO 14001 to legitimize environmental practice but without necessarily improving their environmental performance. Such symbolic adoption of ISO 14001 might result in corporate behavior that undermines the trust in the standard (Ferrón Vílchez, 2017, pp. 37-38).

Ferrón-Vílchez (2016, p. 892) notes in her research that there are four different approaches to adoption of ISO 14001:

- the passive profile (non-certified firms that monitor a narrower array of environmental impacts (or none)),

- the symbolic profile (certified firms that monitor a narrower array of environmental impacts (or none)),

- the invisible profile (non-certified firms that monitor a broad array of environmental impacts), and

- the factual profile (certified firms that monitor a broad array of environmental impacts).

When compared with other three types of firm profiles, firms that comprise the factual profile achieve the greatest environmental performance in terms of the reduction of their negative environmental impacts. Firms that pursue a factual profile are also most likely to achieve positive business performance.

Sartor, Orzes, Touboulic, Culot, and Nassimbeni (2019, p. 52) have found through their research that the greatest barriers to ISO 14001 introduction and certification are the certification procedure and costs related to the procedure and to future certification maintenance. Further barriers include the risk of dissemination of confidential information and difficulties in evaluating results or performance of the environmental management system. On the other hand, Tuppura, Toppinen, and Puumalainen (2015, p. 355) note that the adoption of ISO 14001 certification represents a reactive strategic approach, emphasizing customer satisfaction as a key motivation.

Most organizations that discontinue their ISO 14001 certification are the small ones. The management of these organizations sees the certification maintenance as a cost. Additionally, these organizations do not have sufficient staff that would perform environment-related activities. Moreover, they have a limited capacity to reduce their negative environmental impacts. Therefore, system maintenance and certification become a huge burden, and the primary purpose of the system maintenance gets lost. One of the reasons for discontinuing ISO14001 can be a lack of interest from stakeholders due to which organizations do not 
communicate to them their operations aimed at the reduction of their negative environmental impact. (Mosgaard \& Kristensen, 2020, p. 11)

Given the urgent need for environmental protection, governments of different countries have developed control policies that set targets for energy consumption and emission ceilings. Such policies, however, are often criticized as ineffective. Therefore, since the mid-1990s, the more forward-looking organizations have adopted various voluntary measures to reduce their negative environmental impact with ISO 14001 being the most widely adopted certification (He, Liu, Lu, \& Cao, 2015, p. 43). Traditional government regulations have resulted in significant reduction of industrial pollution, but organizations usually claim that the adoption of such regulations represents significant costs for them. Moreover, government regulations are criticized for setting the ceiling for permissible pollution. Organizations seek to achieve the ceiling levels but when they meet the requirements their activities for further reduction of pollution usually stop. Therefore, many governments have decided to promote organizations' voluntary, permanent and long-term actions to reduce pollution beyond that which is required by law (Arimura, Darnall, Ganguli, \& Katayama, 2016, p. 556).

Arocena, Orcos, and Zouaghi (2020, p. 964) have found through their research that ISO 14001 adoption positively affects an organization's environmental and economic performance. The impact of ISO 14001 is greater for organizations from countries with high environmental awareness of the society than from countries where environmental protection is a lesser issue. The impact of ISO 14001 on an organization's financial and organizational performance proved positive as certified organizations not only attract more customers but also other stakeholders, which contributes to their organizational growth and increased competitiveness. And this greater competitiveness is essential for an organization to remain in the market (Reis, Neves, Hikichi, Salgado, \& Beijo, 2018, p. 12).

ISO 14001 certification has a positive effect on an organization's long-term financial performance in terms of profitability and market benefits (Lee, Noh, Choi, \& Rha, 2017, p. 118). $\mathrm{He}$, Liu, Lu, and Cao (2015, pp. 43-55) have found through their research that the adoption of ISO 14001 increases an organization's sales but also entails considerable costs, such as costs of pollution abatement equipment, costs of pollution control and prevention, costs of certificate maintenance and costs of employee training.

The introduction of ISO 14001 does not have a significant effect on an organization's financial performance in terms of its return on assets (ROA), return on equity (ROE) and return on sales (ROS). Although the ISO 14001 standard was designed to improve environmental practices and performance related thereto, Boiral, Guillaumie, Heras-Saizarbitoria, and Tayo Tene (2017, p. 420) found that organizations that are more successful also focus on socioeconomic aspects, such as improved manufacturing efficiency, cost saving, customer satisfaction, market position, financial performance, investors' returns and share price. Daddi, Frey, De Giacomo, Testa, and Iraldo (2015, pp. 1239-1243) found that the environmental management system can fully deploy its effectiveness in the so-called post-industrial societies where the economies are 
mature enough to adopt and use voluntary and market-based environmental instruments that overcome the traditional approaches, such as legal regulations and taxation.

In view of the theoretical findings, we wanted to examine whether national economies in EU member states have any effect on the number of ISO 14001-certified organizations. We also wanted to explore the trend of the number of certificates in the European Union. The following hypotheses were thus suggested.

Hypothesis 1: »The level of gross domestic product has an impact on the number of ISO 14001 certificates."

Hypothesis 2: "General government expenditure for environmental protection has an impact on the number of ISO 14001 certificates."

Hypothesis 3: "Environmental tax revenues have an impact on the number of ISO 14001 certificates."

Hypothesis 4: „Global competitiveness index ranking has an impact on the number of ISO 14001 certificates.

\section{Method}

Our research was based on the latest publicly available data for 2019. An empirical analysis was conducted on the basis of data on the number of ISO 14001 certificates in 2019, published by ISO, the International Organization for Standardization (ISO Survey 2019, 2021). Data on gross domestic product (hereinafter referred to as GDP), general government expenditure for environmental protection, environmental tax revenues and global competitiveness index ranking for 2019 was obtained from the statistical office of the European Union (Eurostat). Both the International Organization for Standardization and the statistical office of the European Union calculate the listed indicators on the basis of their proven methods. By making the data publicly available, they guarantee their reliability and credibility.

Figure 1 illustrates the research model and the set hypotheses. 


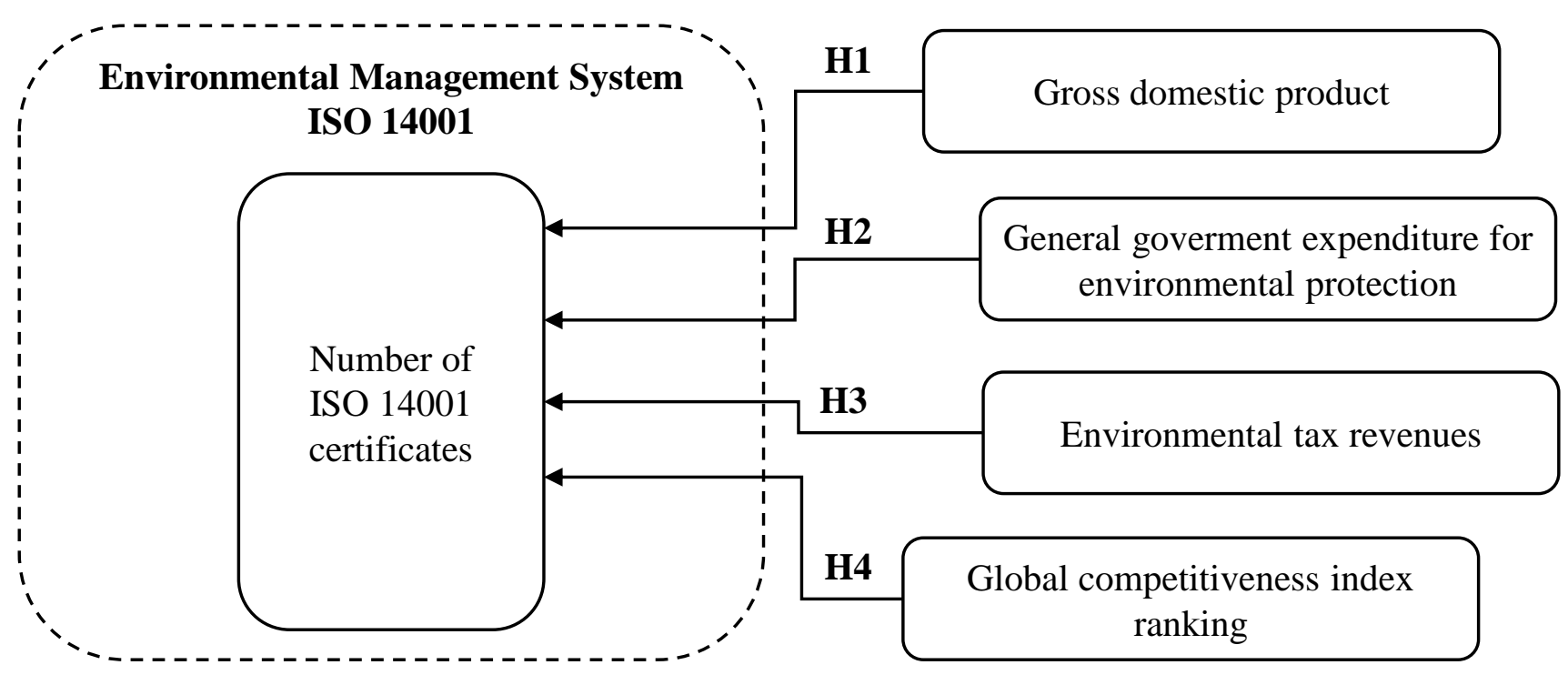

Figure 1. Research model and the set hypotheses.

The sample in our research consisted of the following $28 \mathrm{EU}$ member states in 2019: Austria, Belgium, Bulgaria, Croatia, Cyprus, the Czech Republic, Denmark, Estonia, Finland, France, Germany, Greece, Hungary, Ireland, Italy, Latvia, Lithuania, Luxembourg, Malta, the Netherlands, Poland, Portugal, Romania, Slovakia, Slovenia, Spain, Sweden and the United Kingdom.

The distribution of data that illustrates the number of ISO 14001 certificates by individual EU member states, the number of certificates in relation to gross domestic product in 2019, the number of certificates according to the NACE classification of economic activities and the trend of the number of certificates in the period between 1999 and 2019 is shown by bar charts.

Statistical processing of numerical data used in the analysis was done by means of the Minitab software. Prior to statistical processing, non-normally distributed data on the number of ISO 14001 certificates and GDP was transformed with the Johnson transformation method.

The Pearson correlation coefficient »r« was used to assess the correlation between the number of ISO 14001 certificates and GDP, general government expenditure for environmental protection, environmental tax revenues and global competitiveness index ranking for 2019.

\section{Results}

\subsection{ISO 14001 certificates in European Union member states}

In 2019, there were 92,290 organizations in the European Union (hereinafter referred to as EU) member states that held the ISO 14001 certificate (ISO Survey 2019, 2021). The number of ISO 14001-certified organizations by individual EU member states is shown in Figure 2. 


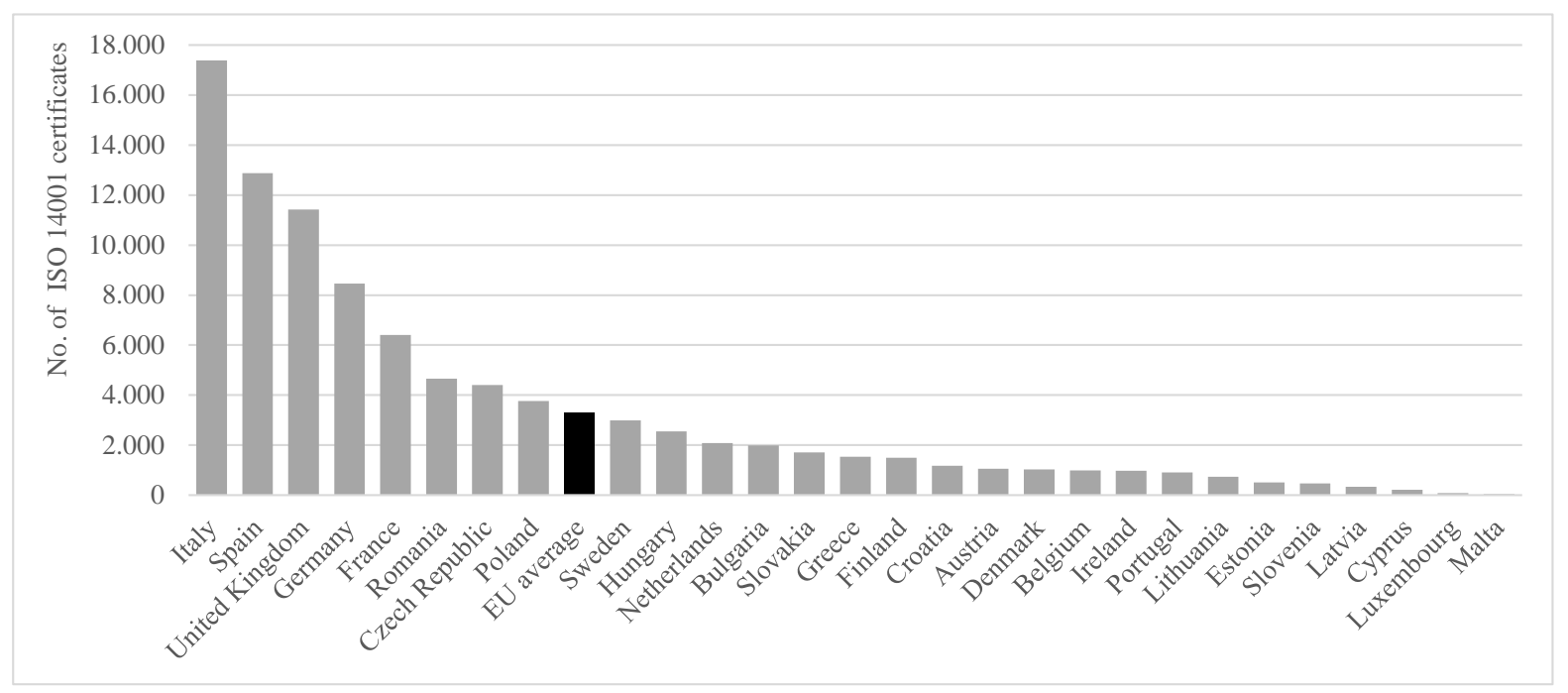

Figure 2. The number of ISO 14001-certified organizations by individual EU member states.

The greatest number of ISO 14001 certificates was held by Italian organizations, followed by those from Spain, the United Kingdom, Germany and France. The EU average number of certificates is shown with a black bar.

The listed EU member states differ in the level of their GDP. Therefore, the number of issued ISO 14001 certificates per one billion EUR of GDP in 2019 in individual states was explored. The number of ISO 14001-certified organizations by individual EU member states by this criterion is shown in Figure 3.

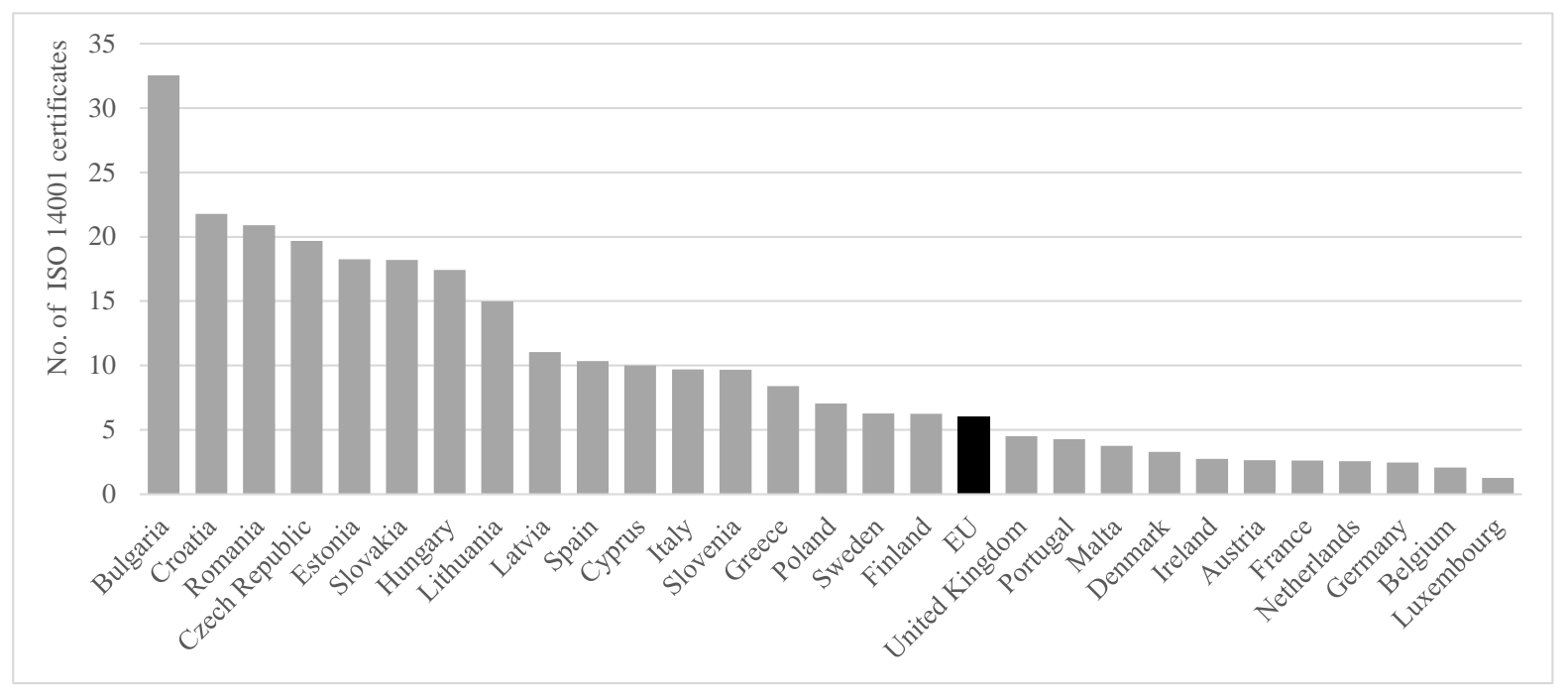

Figure 3. The number of ISO 14001-certified organizations per 1 billion EUR of GDP.

Considering this same criterion, i.e. 1 billion EUR of GDP, the greatest number of ISO 14001certified organizations was found in Bulgaria, followed by Croatia, Romania, the Czech Republic and Estonia. The number of certificates for EU is shown with a black bar in Figure 3 . 
The number of ISO 14001-certified organizations in view of the Eurostat classification of economic activities (NACE) is shown in Figure 4. Figure 4 illustrates economic activities in which more than 1,000 ISO 14001-certified organizations performed their operations (ISO Survey 2019, 2021).

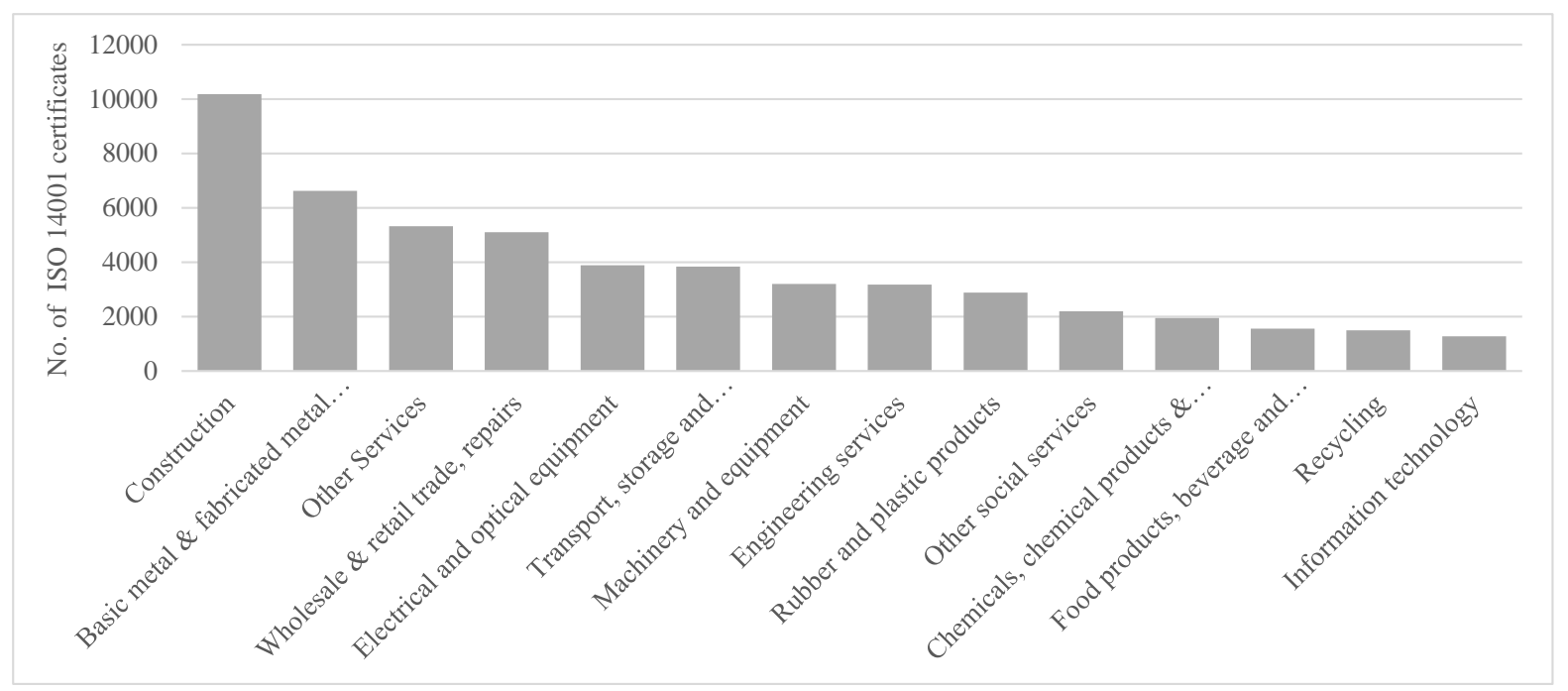

Figure 4. The number of ISO 14001-certified organizations in view of the classification of economic activities.

The greatest number of ISO 14001-certified organizations operated in the construction sector, followed by the basic metal \& fabricated metal products sector, other services, wholesale \& retail trade, repairs, and electrical and optical equipment sector.

The trend in the number of ISO 14001 certificates in EU between 1999 and 2019 is shown in Figure 5.

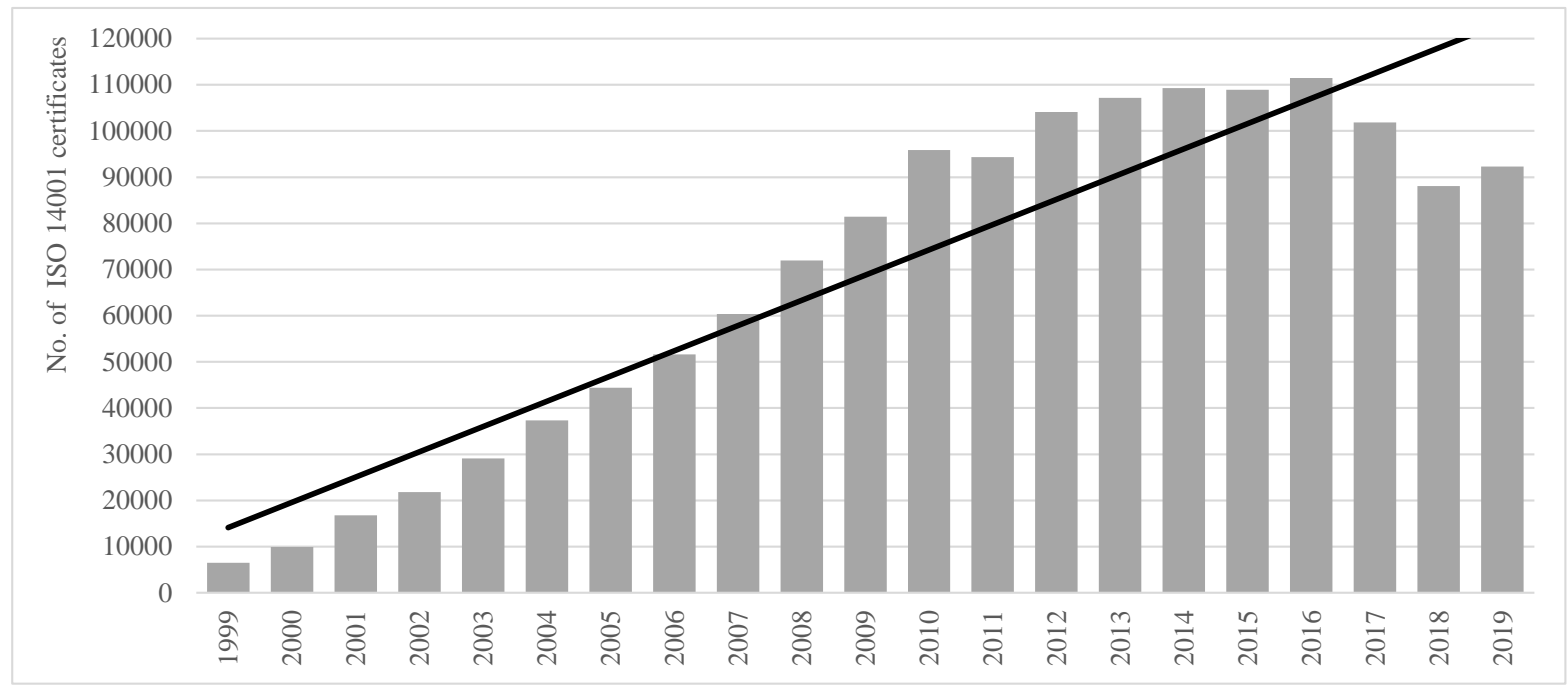

Figure 5. The number of ISO 14001-certified organizations in EU between 1999 and 2019. 
There was a constant increase in the number of issued certificates in the period between 1999 and 2010. There was a minimal decline in 2011, followed by resumed growth from 2012 to 2016. The number of ISO 14001 certificates dropped in 2017, as the method of counting the issued certificates in Italy changed. The drop in the number of certificates in EU in 2018 can be ascribed to the general economic crisis, while in 2019, the number of certificates started increasing again. The black line in the chart in Figure 5 illustrates a positive trend in the number of ISO 14001 certificates in EU.

\subsection{Correlation between chosen factors of national economies and number of ISO 14001 certificates}

The impact of individual factors on the number of ISO 14001 certificates explored in the hypotheses was examined by means of the Pearson correlation coefficients $» r$ «. Our research included a survey of $28 \mathrm{EU}$ member states $(\mathrm{N}=28)$. With regard to confidence level of $95 \%$ and significance level $a$ at 0.05 , the critical value of the Pearson correlation coefficient is at 0.361. In the examination of correlations illustrated in Table 1, the critical value of the Pearson correlation coefficient was taken into consideration.

Potential correlations between the number of ISO 14001 certificates and GDP, general government expenditure for environmental protection, environmental tax revenues and global competitiveness index ranking for 2019 are shown in Table 1.

Table 1. The Pearson coefficient values for correlation between the number of ISO 14001 certificates and chosen factors.

\begin{tabular}{ll}
\hline & \multicolumn{1}{c}{ No. of ISO 14001 certificates } \\
\hline Gross domestic product (GDP) & $\mathrm{r}=\mathbf{0 . 8 4 4}$ \\
& Confidence interval $(\mathrm{CI})=0.688 ; 0.926$ \\
& $\mathrm{p}<0.001$ \\
& Standard deviation $=888397$ \\
\hline General government expenditure for environmental & $\mathrm{r}=-0,004$ \\
protection & Confidence interval $(\mathrm{CI})=-0.376 ; 0.370$ \\
& $\mathrm{p}<0.984$ \\
& Standard deviation $=0,3326$ \\
\hline Environmental tax revenues & $\mathrm{r}=-0,131$ \\
& Confidence interval $(\mathrm{CI})=-0.481 ; 0.254$ \\
& $\mathrm{p}<0.506$ \\
& Standard deviation $=0,625$ \\
\hline Global competitiveness index rating & $\mathrm{r}=0.250$ \\
& Confidence interval $(\mathrm{CI})=-0.136 ; 0.570$ \\
& $\mathrm{p}<0.199$ \\
& Standard deviation $=6,46$ \\
\hline
\end{tabular}

The correlation coefficient between GDP and the number of ISO 14001 certificates has a significant positive value of $\mathbf{0 . 8 8 4}$, indicating a strong correlation between the two. 
There is an insignificant correlation between general government expenditure for environmental protection and the number of ISO 14001 certificates, as the calculated value of the Pearson correlation coefficient is that of -0.004 .

The same applies to the correlation between environmental tax revenues and the number of ISO 14001 certificates, where the calculated value of the Pearson correlation coefficient is at -0.131 .

The correlation coefficient between the global competitiveness index rating and the number of ISO 14001 certificates has a value of 0.250 , indicating a weak positive correlation between the two factors.

\section{Discussion}

Our research included a survey of $28 \mathrm{EU}$ member states in 2019. At the time, there were 92,290 organizations that held the ISO 14001 certificate (ISO Survey 2019, 2021). The country with the highest number of issued ISO 14001 certificates was Italy (17,386 certificates), followed by Spain $(12,871)$, the United Kingdom $(11,420)$, Germany $(8,465)$ and France $(6,402$ certificates). Fura and Wang (2017, pp. 114-115) found that the top three countries with the largest number of ISO 14001 certificates in as early as in 2011 and 2012 were Italy, Spain and the United Kingdom. Taking into account absolute numbers, the largest quantity of organizations having an environmental management system in accordance with the requirements of ISO 14001 occurs in the largest EU member states (Olkiewicz, Wolniak, \& Skotnicka-Zasadzień, 2019, p. 873). The top five EU member states with the highest number of ISO 14001 certificates included in our research are the so-called »older member states«, followed by Romania, the Czech Republic and Poland which joined the EU after 2004. In view of the number of issued certificates, all listed states were above the EU average of 3,296 certificates (see Figure 2). 20 EU member states are below average.

Due to the fact that European Union countries vary in size, number of inhabitants, economic indicators, etc., there is no point in comparing the absolute numbers of ISO 14001 certificates because, understandably, the larger the country the more certificates implemented (Olkiewicz, Wolniak, \& Skotnicka-Zasadzień, 2019, p. 873). The comparison was thus made in view of the number of certificates issued in individual states in 2019 per one billion EUR of GDP. Comparison of the number of certificates in view of the common denominator showed that the greatest number of ISO 14001-certified organizations was in Bulgaria. The four countries that followed were Croatia, Romania, the Czech Republic and Estonia. These are the so-called »new member states « that joined the EU after 2004. Organizations in these countries more frequently decide for ISO 14001 certification. ISO 14001 environmental certification occurs more frequently in countries with medium economic backwardness when compared with highly developed countries (Olkiewicz, Wolniak, \& Skotnicka-Zasadzień, 2019, p. 877). Fura and Wang (2017, p. 115) also note that the interest of organizations in ISO 14001 certification is higher in less developed countries. The number of ISO 14001 certificates per one billion EUR 
of GDP in EU is six, whereby 17 member states exceed that number and 11 states are below it (see Figure 3).

The distribution of the number of issued ISO 14001 certificates in relation to the economic activity in which a certified organization operates (according to the Eurostat classification of economic activities, NACE) shows that the greatest number of certified organizations operate in the construction sector, amounting to $10 \%$ of all certified organizations. $7 \%$ of all certified organizations come from the basic metal \& fabricated metal products sector, while $5 \%$ of them operate in other services sector (see Figure 4).

The number of ISO 14001 certificates issued over a longer period of time, between 1999 and 2019, was analyzed. There was a constant growth of the number of certificates from 1999 to 2016, with a minimal decline in 2011 (see Figure 5). Sousa Lira, Gomes Salgado, and Alberto Beijo (2019, p. 277) also note that the number of ISO 14001 certificates has significantly increased since it was first published in 1996. In 2017, there was a drop in the number of certificates, resulting from a change in the method of recording the issued certificates in Italy. Thus, the recorded number of certificates in 2016 in Italy was 26,655; in 2017, the number dropped to 14,571 (ISO Survey 2019, 2021). The economic crisis in 2018 had a negative impact on the interest of organizations in certification, and the drop in the number of certificates could also be ascribed to the decision of organizations to discontinue certification or to no longer maintain it. Mosgaard and Kristensen (2020, p. 11) note that it is mainly small and mediumsized companies that decide to discontinue certification, while in times of economic and financial crises, the business community seems to be even less interested in organizations that give priority to environmental issues (Di Noia \& Nicoletti, 2016, p. 94).

A resumed growth in the number of certificates is evident in 2019 when the numbers increased by 5\% compared to 2018. The trend in the growth of the number of ISO 14001 certificates between 1999 and 2019 is positive.

Hypotheses set in our research and presented in Chapter 2 have been verified by means of the Pearson correlation coefficients »r« (see Chapter 4.2.).

Hypothesis 1: »The level of gross domestic product has an impact on the number of ISO 14001 certificates."

The calculated correlation coefficient between GDP and the number of ISO 14001 certificates in EU member states in $2019(\mathrm{r}=\mathbf{0 . 8 8 4})$ has a significant positive value, as it exceeds the critical value of the Pearson correlation coefficient, which is $\mathbf{0 . 3 6 1}$. Thus, the correlation between GDP and the number of ISO 14001 certificates is strong (see Table 1). The results of research conducted by Fura and Wang (2017, pp. 117-118) have shown that the level of national socioeconomic development is a factor associated with the diffusion of ISO 14001 environmental management system in EU countries, while Olkiewicz, Wolniak, and SkotnickaZasadzień (2019, pp. 876-877) note in their research that there is a negative relationship between GDP and the number of ISO 14001-certified organizations in EU countries. Our 
finding is in opposition to the above written. On the basis of our calculations, Hypothesis 1 was therefore confirmed.

Hypothesis 2: "General government expenditure for environmental protection has an impact on the number of ISO 14001 certificates."

The correlation coefficient between general government expenditure for environmental protection and the number of ISO 14001 certificates that was calculated in our research amounts to -0.004 , indicating an insignificant correlation between the two factors (see Table 1). Orcos, Pérez-Aradros, and Blind (2018, p. 859) claim that state institutions have an impact on increased interest in ISO 14001 certification, which they can assert through their power at a macro-level and through their environmental strategies. Liu, Yuan, Hafeez, and Li (2019, p. 1259) state that governments of developing countries or those with low environmental awareness should establish strong environmental institutions and strategies that would encourage ISO 14001 certification and thus have a positive impact on national environmental management. On the basis of the calculated coefficient, Hypothesis 2 was rejected.

Hypothesis 3: »Environmental tax revenues have an impact on the number of ISO 14001 certificates."

The correlation coefficient between environmental tax revenues and the number of ISO 14001 certificates amounts to - 0.131 (see Table 1). Thus, there is an insignificant correlation between the two factors. Traditional approaches, such as taxation, do not contribute to an increased number of certificates or to the development of ISO 14001 environmental management systems. Daddi, Frey, De Giacomo, Testa, and Iraldo (2015, pp. 1239-1243) have found that the interest in ISO 14001 can only be increased in mature economies where it is possible to adopt and use voluntary and market-based environmental instruments that overcome the traditional approaches. On the basis of the calculated correlation coefficient, Hypothesis 3 was rejected.

Hypothesis 4: "Global competitiveness index ranking has an impact on the number of ISO 14001 certificates. «

The correlation coefficient between the global competitiveness index rating and the number of ISO 14001 certificates amounts to 0.250 in our research, indicating a weak positive correlation between the two factors. Thus, the global competitiveness index rating does not significantly affect the number of ISO 14001 certificates obtained by organizations in an individual country. Fura and Wang (2017, pp. 117-118) state that there is a higher interest in the ISO 14001 adoption by firms from less developed countries than by those located in the highly developed states. On the basis of the calculated correlation coefficient, Hypothesis 4 was rejected.

Confirmation and rejection of hypotheses was made easier by the calculated Pearson correlation coefficients. In case of Hypothesis 1, the coefficient had a significant value on the basis of which a strong correlation was observed between the discussed factors, while with the 
remaining hypotheses, the correlation coefficient had an insignificant or weak value, indicating that there was no correlation between the examined factors.

\section{Conclusion}

Our study presents the situation regarding the number of ISO 14001 certificates issued to organizations that operated in EU member states in 2019. ISO, the International Organization for Standardization, last published the data on the number of certificates for year 2019 (ISO Survey 2019, 2021). The primary purpose of the research was to obtain the answer to our research problem of whether national economies in EU member states affect the number of organizations that have the certified ISO 14001 environmental management system in place. The national economy parameters discussed in our research were GDP, general government expenditure for environmental protection, environmental tax revenues and global competitiveness index rating.

The results of our research showed that there were 92,290 ISO 14001-certified organizations in EU member states in 2019 (ISO Survey 2019, 2021). In absolute numbers of certificates, it was the so-called »older EU member states« that stood out, with Italy in the first place, followed by Spain, the United Kingdom, Germany and France. Olkiewicz, Wolniak, \& Skotnicka-Zasadzień $(2019$, p. 873) also found in their research that the largest absolute number of organizations having an environmental management system in accordance with the requirements of ISO 14001 occurs in the largest EU member states.

Unlike the research conducted by Fura and Wang (2017, p. 103) in which they explored the impact of socioeconomic development on the number of ISO 14001 certificates, our study analyzed the correlation between the national economy and number of certificates. In 2019, the highest number of ISO 14001 certificates per one billion EUR of GDP was observed in Bulgaria, followed by Croatia, Romania, the Czech Republic and Estonia. These are the socalled »new member states « that have overtaken the »older member states « in terms of these numbers. Our finding matches the results of study conducted by Olkiewicz, Wolniak, and Skotnicka-Zasadzien $(2019$, p. 877) who found that less developed countries are more likely to decide for ISO 14001 certification than the developed ones. Organizations from less developed countries want to enter international markets and perceive ISO 14001 certificates as a convenient way to prove that they operate in accordance with the modern environmental policy.

Among the four hypotheses proposed, the most important - Hypothesis 1 - was confirmed. It was namely observed that there is a strong correlation between GDP and the number of ISO 14001 certificates in EU member states. Daddi, Frey, De Giacomo, Testa, and Iraldo (2015, p. 1250) also note that the increase in the number of certificates is related to the increase in selected macroeconomic indexes. Other three hypotheses were rejected because no correlation was found between general government expenditure for environmental protection, environmental tax revenues, global competitiveness index rating and number of ISO 14001 certificates. In this regard, Preziosi, Merli, and D'Amico (2016, p. 8) note that an important aspect the governments 
should consider is that measures, such as tax incentives, should be effective in the long run to facilitate ISO 14001 certification and avoid abandonments after obtaining the incentive.

The situation in terms of the number of certificates in EU has been explored in a number of studies (Sousa Lira, Gomes Salgado, \& Alberto Beijo, 2019, p. 276; Fura \& Wang, 2017, p. 103; Olkiewicz, Wolniak, \& Skotnicka-Zasadzień, 2019, p. 877; Salim et al., 2018, p. 1). An analysis of possible correlation between GDP as a macroeconomic indicator of a national economy and the number of certificates was found only in the study performed by Olkiewicz, Wolniak, and Skotnicka-Zasadzien (2019, p. 871) who, contrary to the findings of our research, assert that there is a negative correlation between GDP and the number of ISO 14001-certified organizations in EU countries. In line with the confirmation of Hypothesis 1, our finding is in opposition to this observation. Olkiewicz, Wolniak, and Skotnicka-Zasadzień (2019, p. 871) included in their research 26 EU member states. They left out Croatia and the Czech Republic, while our study included all $28 \mathrm{EU}$ member states. Considering the completeness of the study of EU member states and the fact that the latest publicly available data on the number of certificates in 2019 (ISO Survey 2019, 2021) was used, it is our belief that our research is unique from this point of view.

Organizations and companies from EU member states can use our study to obtain information on the number of ISO 14001 certificates in individual EU member states or in the EU as a whole. Moreover, the evident positive trend in the growth of the number of certificates can be an additional motivation factor for those organizations that have yet to decide on certification. One of the main findings of our research is also the fact that the certified ISO 14001 environmental management system is a useful and effective management tool, bringing enhanced environmental performance and sustainability, competitive advantage as well as financial and organizational performance. Because our study did not find any positive impacts of tax expenditure and general government expenditure for environmental protection, state institutions could direct their resources into finding new strategies that would, contrary to the mentioned traditional approaches, stimulate organizations to obtain the ISO 14001 certificate.

Given that Slovenia is an EU member state, our research was narrowed down to $28 \mathrm{EU}$ member states. The hypotheses were verified on the basis of the latest publicly available data for 2019 published by ISO, the International Organization for Standardization.

Based on our research, it would make sense to conduct a new research and, in addition to four factors that we discussed, examine other national macroeconomic indicators. Thus, it would be possible to establish which factors, in addition to GDP, have a positive impact on the growth of the number of ISO 14001 certificates. Moreover, the research could also include other countries on the European continent that are not necessarily EU member states. Thus, a better insight would be gained into the situation regarding environmental management system certification. 


\section{References}

1. Arimura, T. H., Darnall, N., Ganguli, R., \& Katayama, H. (2016). The effect of ISO 14001 on environmental performance: Resolving equivocal findings. Journal of Environmental Management, 166, 556-566. doi: 10.1016/j.jenvman.2015.10.032

2. Arocena, P., Orcos, R., \& Zouaghi, F. (2020). The impact of ISO 14001 on firm environmental and economic performance: The moderating role of size and environmental awareness. Business Strategy and the Environment, 30(2), 955-967. doi: 10.1002/bse.2663

3. Boiral, O., Guillaumie, L., Heras-Saizarbitoria, I., \& Tayo Tene, C. V. (2017). Adoption and outcomes of ISO 14001: A Systematic Review. International Journal of Management Reviews, 20(2), 411-432. doi: 10.1111/ijmr.12139

4. Bravi, L., Santos, G., Pagano, A., \& Murmura, F. (2020). Environmental management system according to ISO 14001:2015 as a driver to sustainable development. Corporate Social Responsibility and Environmental Management, 27(6), 2599-2614. doi: 10.1002/csr.1985

5. Campos, L. M. S., de Melo Heizen, D. A., Verdinelli, M. A., \& Cauchick Miguel, P. A. (2015). Environmental performance indicators: a study on ISO 14001 certified companies. Journal of Cleaner Production, 99, 286-296. doi: 10.1016/j.jclepro.2015.03.019

6. Chiarini, A. (2017). Setting strategies outside a typical environmental perspective using ISO 14001 certification. Business Strategy and the Environment, 26(6), 844-854. doi: 10.1002/bse.1969

7. Chiarini, A. (2019). Factors for succeeding in ISO 14001 implementation in Italian construction industry. Business Strategy and the Environment, 28(5), 794-803. doi: 10.1002/bse.2281

8. Ciravegna Martins da Fonseca, L. M. (2015). ISO 14001:2015: An improved tool for sustainability. Journal of Industrial Engineering and Management, 8(1), 37-50. doi: 10.3926/jiem. 1298

9. Daddi, T., Frey, M., De Giacomo, M. R., Testa, F., \& Iraldo, F. (2015). Macro-economic and development indexes and ISO14001 certificates: a cross national analysis. Journal of Cleaner Production, 108, 1239-1248. doi: 10.1016/j.jclepro.2015.06.091

10. Di Noia, A. E., \& Nicoletti, G. M. (2016). ISO 14001 certification: benefits, costs and expectations for organization. Studia Oeconomica Posnaniensia, 4(10), 94-109. doi: 10.18559/soep.2016.10.7

11. Ejdys, J., Matuszak-Flejszman, A., Szymanski, M., Ustinovichius, L., Shevchenko, G., \& Lulewicz-Sas, A. (2016). Crucial factors for improving the ISO 14001 environmental management system. Journal of Business Economics and Management, 17(1), 52-73. doi: 10.3846/16111699.2015.1065905

12. Erauskin-Tolosa, A., Zubeltzu-Jaka, E., Heras-Saizarbitoria, I., \& Boiral, O. (2020). ISO 14001, EMAS and environmental performance: A meta-analysis. Business Strategy and the Environment, 29(3), 1145-1159. doi: 10.1002/bse.2422

13. Eurostat. (2021). Retrived from https://ec.europa.eu

14. Ferrón-Vílchez, V. (2016). Does symbolism benefit environmental and business performance in the adoption of ISO 14001? Journal of Environmental Management, 183, 882-894. doi: 10.1016/j.jenvman.2016.09.047

15. Ferrón Vílchez, V. (2017). The dark side of ISO 14001: The symbolic environmental behavior. European Research on Management and Business Economics, 23(1), 33-39. doi: 10.1016/j.iedeen.2016.09.002 
16. Fura, B., \& Wang, Q. (2017). The level of socioeconomic development of EU countries and the state of ISO 14001 certification. Quality \& Quantity, 5l(1), 103-119. doi: 10.1007/s11135-0150297-7

17. He, W., Liu, C., Lu, J., \& Cao, J. (2015). Impacts of ISO 14001 adoption on firm performance: Evidence from China. China Economic Review, 32, 43-56. doi: 10.1016/j.chieco.2014.11.008

18. Hikichi, S. E., Salgado, E. G., \& Beijo, L. A. (2017). Forecasting number of ISO 14001 certifications in the Americas using ARIMA models. Journal of Cleaner Production, 147, 242253. doi: 10.1016/j.jclepro.2017.01.084

19. Hojnik, J., \& Ruzzier, M. (2017). Does it pay to be eco? The mediating role of competitive benefits and the effect of ISO14001. European Management Journal, 35(5), 581-594. doi: 10.1016/j.emj.2017.07.008

20. Ikram, M., Mahmoudi, A., Syed Zulfiqar, A. S., \& Mohsin, M. (2019). Forecasting number of ISO 14001 certifications of selected countries: application of even GM $(1,1)$, DGM, and NDGM models. Environmental Science and Pollution Research, Iea 2015, 1-17. doi: 10.1007/s11356-01904534-2

21. Ikram, D. M., Zhang, P. Q., Sroufe, P. R., \& Shah, P. S. Z. A. (2020). Towards a sustainable environment: The nexus between ISO 14001, renewable energy consumption, access to electricity, agriculture and $\mathrm{CO}_{2}$ emissions in SAARC countries. Sustainable Production and Consumption, 22, 218-230. doi: 10.1016/j.spc.2020.03.011

22. ISO. (2021). ISO Survey 2019. Retrived from https://www.iso.org/the-iso-survey.html

23. Lee, S. M., Noh, Y., Choi, D., \& Rha, J. S. (2017). Environmental policy performances for sustainable development: From the perspective of ISO 14001 Certification. Corporate Social Responsibility and Environmental Management, 24(2), 108-120. doi: 10.1002/csr.1395

24. Liu, J., Yuan, C., Hafeez, M., \& Li, X. (2019). ISO 14001 certification in developing countries: motivations from trade and environment. Journal of Environmental Planning and Management, 63(7), 1241-1265. doi: 10.1080/09640568.2019.1649642

25. Maletič, M., Podpečan, M., \& Maletič, D. (2015). ISO 14001 in a corporate sustainability context: a multiple case study approach. Management of Environmental Quality: An International Journal, 26(6), 872-890. doi: 10.1108/meq-08-2014-0129

26. Merli, R., \& Preziosi, M. (2018). The EMAS impasse: Factors influencing Italian organizations to withdraw or renew the registration. Journal of Cleaner Production, 172, 4532-4543. doi: 10.1016/j.jclepro.2017.11.031

27. Mosgaard, M. A., \& Kristensen, H. S. (2020). Companies that discontinue their ISO14001 certification - Reasons, consequences and impact on practice. Journal of Cleaner Production, 260, 1-12. doi: $10.1016 /$ j.jclepro.2020.121052

28. Murmura, F., Liberatore, L., Bravi, L., \& Casolani, N. (2018). Evaluation of Italian companies' perception about ISO 14001 and eco management and audit scheme III: Motivations, benefits and barriers. Journal of Cleaner Production, 174, 691-700. doi: 10.1016/j.jclepro.2017.10.337

29. Oliveira, J. A., Oliveira, O. J., Ometto, A. R., Ferraudo, A. S., \& Salgado, M. H. (2016). Environmental management system ISO 14001 factors for promoting the adoption of cleaner production practices. Journal of Cleaner Production, 133, 1384-1394. doi: 10.1016/j.jclepro.2016.06.013

30. Olkiewicz, M., Wolniak, R., \& Skotnicka-Zasadzień, B. (2019). Implementation of ISO 14001 standard in the european union countries. Rocznik Ochrona Srodowiska, 21(2), 868-880.

31. Orcos, R., Pérez-Aradros, B., \& Blind, K. (2018). Why does the diffusion of environmental management standards differ across countries? The role of formal and informal institutions in the 
adoption of ISO 14001. Journal of World Business, 53(6), 850-861. doi:

10.1016/j.jwb.2018.07.002

32. Ozusaglam, S., Robin, S., \& Wong, C. Y. (2017). Early and late adopters of ISO 14001-type standards: revisiting the role of firm characteristics and capabilities. The Journal of Technology Transfer, 43(5), 1318-1345. doi: 10.1007/s10961-017-9560-5

33. Polasky, S., Kling, C. L., Levin, S. A., Carpenter, S. R., Daily, G. C., Ehrlich, P. R., ... Lubchenco, J. (2019). Role of economics in analyzing the environment and sustainable development. Proceedings of the National Academy of Sciences, 116(12), 5233-5238. doi: 10.1073/pnas.1901616116

34. Preziosi, M., Merli, R., \& D’Amico, M. (2016). Why companies do not renew their EMAS registration? An exploratory research. Sustainability, 8(2), 1-11. doi: 10.3390/su8020191

35. Reis, A. V., Neves, F. de O., Hikichi, S. E., Salgado, E. G., \& Beijo, L. A. (2018). Is ISO 14001 certification really good to the company? a critical analysis. Production, 28(0), 1-16. doi: 10.1590/0103-6513.20180073

36. Riaz, H., Saeed, A., Baloch, M., Nasrullah, \& Khan, Z. (2019). Valuation of environmental management standard ISO 14001: Evidence from an emerging market. Journal of Risk and Financial Management, 12(1), 1-14. doi: 10.3390/jrfm12010021

37. Salim, H. K., Padfield, R., Hansen, S. B., Mohamad, S. E., Yuzir, A., Syayuti, K., ... Papargyropoulou, E. (2018). Global trends in environmental management system and ISO 14001 research. Journal of Cleaner Production, 170, 645-653. doi: 10.1016/j.jclepro.2017.09.017

38. Sartor, M., Orzes, G., Touboulic, A., Culot, G., \& Nassimbeni, G. (2019). ISO 14001 standard: Literature review and theory-based research agenda. Quality Management Journal, 26(1), 32-64. doi: 10.1080/10686967.2018.1542288

39. Singh, M., Brueckner, M., \& Padhy, P. K. (2015). Environmental management system ISO 14001: effective waste minimisation in small and medium enterprises in India. Journal of Cleaner Production, 102, 285-301. doi: 10.1016/j.jclepro.2015.04.028

40. Sorooshian, S., Qi, L. C., \& Li Fei, L. (2018). Characterization of ISO 14001 implementation. Environmental Quality Management, 27(3), 97-105. doi: 10.1002/tqem.21532

41. Sousa Lira, J. M., Gomes Salgado, E., \& Alberto Beijo, L. (2019). ARIMA models as an alternative to predict the diffusion of the ISO 14001 standard in Europe. Journal of Environmental Planning and Management, 63(2), 275-286. doi: 10.1080/09640568.2019.1577721

42. Tarí, J. J., Molina-Azorín, J. F., \& Heras, I. (2012). Benefits of the ISO 9001 and ISO 14001 standards: A literature review. Journal of Industrial Engineering and Management, 5(2), 297-322. doi: $10.3926 /$ jiem.488

43. Treacy, R., Humphreys, P., McIvor, R., \& Lo, C. (2019). ISO14001 certification and operating performance: A practice-based view. International Journal of Production Economics, 208(March 2018), 319-328. doi: 10.1016/j.ijpe.2018.12.012

44. Tuppura, A., Toppinen, A., \& Puumalainen, K. (2015). Forest certification and ISO 14001: Current state and motivation in forest companies. Business Strategy and the Environment, 25(5), 355-368. doi: 10.1002/bse.1878 
Stojan Črv is a doctoral student of Quality Management at the Faculty of Organization Studies in Novo mesto. He has a Master's Degree in Business Sciences and a BSc in Mechanical Engineering. He has also completed the Six Sigma Black Belt training. Mr Črv has been working in the field of quality for more than 20 years and is the quality manager at industrial enterprise ITW Appliance Components d.o.o., which is a part of the American multinational corporation ITW. He is also an external or leading auditor of the quality management system according to ISO 9001 standard, of the environmental management system according to ISO 14001 standard as well as of the occupational health and safety management system according to ISO 45001 standard.

$* * *$

\section{Povzetek: \\ Sistem ravnanja $z$ okoljem ISO 14001 in nacionalna gospodarstva v državah članicah EU}

Raziskovalno vprašanje (RV): Glede na naraščajoč pomen okoljske ozaveščenosti je bilo naše glavno raziskovalno vprašanje, ali nacionalna gospodarstva v državah članicah EU vplivajo na število organizacij s certifikatom ISO 14001.

Namen: Primarni namen raziskave je bil pridobiti odgovor na naš raziskovalni problem, ali nacionalna gospodarstva $v$ državah članicah EU vplivajo na število organizacij, ki imajo certificiran sistem ravnanja z okoljem ISO 14001 in raziskati trend števila certifikatov v Evropski uniji.

Metoda: Empirično analizo smo izvedli na podlagi podatkov mednarodne organizacije za standardizacijo ISO o številu certifikatov ISO 14001 za leto 2019 ter podatkov Eurostata za izbrane makroekonomske kazalnike nacionalnih gospodarstev. V raziskavi smo obravnavali 28 držav članic Evropske unije v letu 2019. Distribucijo podatkov smo prikazali s stolpčnimi grafikoni. Numerične podatke, uporabljene $\mathrm{v}$ analizi, smo statistično obdelali $\mathrm{z}$ uporabo programske opreme Minitab. Nenormalno porazdeljene podatke smo pred statistično obdelavo transformirali $\mathrm{z}$ uporabo Johnsonove transformacijske metode. Preverjanje hipotez smo izvedli na podlagi izračunanih Pearsonovih koeficientov korelacije »r« med posameznimi obravnavanimi faktorji.

Rezultati: V letu 2019 je bilo v državah članicah EU 92.290 organizacij s certifikatom ISO 14001. Po absolutnem številu certifikatov so na prvih petih mestih tako imenovane »starejše članice« EU, in sicer Italija, Španija, Združeno Kraljestvo, Nemčija in Francija. Največje število certifikatov na eno milijardo EUR BDP imajo tako imenovane »nove članice« Bolgarija, Hrvaška, Romunija, Češka in Estonija. Glavna ugotovitev naše raziskave je, da višina BDP vpliva na število certifikatov ISO 14001 v državah članicah EU, saj glede na izračunani Pearsonov koeficient korelacije med obravnavanima faktorjema obstaja močna povezanost. Ostali obravnavani makroekonomski faktorji nacionalnih gospodarstev, kot so izdatki države za varstvo okolja, prihodki od okoljskih davkov in ocena indeksa globalne konkurenčnosti, nimajo vpliva na število certifikatov ISO 14001.

Organizacija: Raziskava omogoča organizacijam vpogled v stanje na področju števila certifikatov ISO 14001 v državah članicah EU. Prikazan pozitiven trend rasti števila certifikatov je lahko dodaten motivacijski faktor organizacijam, ki se za certifikacijo šele odločajo.

Družba: Glavna ugotovitev, da je certificiran sistem ravnanja z okoljem po standardu ISO 14001 koristno in učinkovito orodje upravljanja, ki prinaša večjo okoljsko učinkovitost in trajnost, konkurenčno prednost ter finančno in organizacijsko uspešnost je pomembna tako za organizacije, kot tudi za širšo družbo.

Originalnost: Glede na to, da je naša raziskava vključevala vseh 28 držav članic EU v letu 2019 in, da so bili uporabljeni najnovejši javno dostopni podatki o številu certifikatov ISO 14001 v letu 2019, menimo, da je naša raziskava s tega vidika edinstvena.

Omejitve/nadaljnje raziskovanje: Raziskavo smo omejili na 28 držav članic EU. Hipoteze smo preverjali glede na zadnje javno dostopne podatke za leto 2019, objavljene s strani mednarodne organizacije za standardizacijo ISO. Smiselno bi bilo nadaljevati našo raziskavo tako, da bi poleg štirih faktorjev, ki smo jih obravnavali, obravnavali še dodatne makroekonomske kazalnike nacionalnih gospodarstev. Na ta način bi lahko ugotovili, če še kateri drugi faktorji, poleg BDP, pozitivno prispevajo $\mathrm{k}$ rasti števila certifikatov ISO 14001. Lahko pa bi v obravnavo zajeli še ostale države evropskega kontinenta, ki niso članice EU. 
Revija za univerzalno odličnost / Journal of Universal Excellence,

September 2021, leto / year 10, številka / number 3, str. / pp. 267-288.

Ključne besede: sistem ravnanja z okoljem, ISO 14001, certifikacija, varovanje okolje, kazalniki nacionalnega gospodarstva, Evropska unija.

Copyright (c) Stojan ČRV

\section{(c) (†) (2)}

Creative Commons License

This work is licensed under a Creative Commons Attribution-ShareAlike 4.0 International License. 